\author{
ANNA KolASIŃSKA \\ Uniwersytet Pedagogiczny w Krakowie, Polska \\ Pedagogical University of Krakow, Poland \\ JOANNA SPOREK \\ Uniwersytet Pedagogiczny w Krakowie, Polska \\ Pedagogical University of Krakow, Poland
}

\title{
Preferencje turystyczne seniorów - słuchaczy krakowskich uniwersytetów trzeciego wieku
}

\section{Tourist preferences of seniors - participants of Krakow Universities of the Third Age}

\begin{abstract}
Streszczenie: Postępujący proces starzenia się społeczeństw obserwowany jest na całym świecie, a turystyka jest jednym ze sposobów na aktywizację osób w wieku senioralnym. Celem niniejszej pracy jest określenie głównych preferencji seniorów w zakresie różnych aspektów związanych z podejmowaniem aktywności turystycznej. Istotną częścią pracy było także wskazanie barier, które ograniczają seniorów w podróżowaniu. $\mathrm{W}$ pracy zastosowano badania ankietowe przeprowadzone na grupie seniorów zrzeszonych w wybranych uniwersytetach trzeciego wieku (dalej UTW) w Krakowie. Na podstawie badań stwierdzono, że słuchacze UTW należą do grupy aktywnych turystycznie seniorów odbywających zazwyczaj podróże krajowe w celach turystyczno-wypoczynkowych. Ponadto seniorzy decydują się na wypoczynek poza sezonem, a jako główną barierę wojaży wskazali ograniczone możliwości finansowe. Zaprezentowane w pracy wyniki badań mogą okazać się przydatne dla branży turystyczno-hotelarskiej, która powinna docenić potencjał turystyki senioralnej zwłaszcza w kontekście funkcjonowania ośrodków turystycznych poza głównym sezonem wakacyjnym.
\end{abstract}

\begin{abstract}
The progressive aging process of societies is observed worldwide and tourism is one of the ways to activate elder people. The aim of this study is to identify the main preferences of seniors in various aspects related to tourism activities, as well as barriers that might limit or even prevent them from travelling. The study was based on a questionnaire survey carried out on a group of seniors associated in selected universities of the third age in Krakow. Based on the research, it was found that the participants of the study belong to a group of active seniors who usually travel domestically for tourism and leisure purposes. In addition, they prefer off-season holidays, and indicate financial limitations as the main barrier. The findings presented in this study may prove useful for the tourism and hotel industry, which should appreciate the potential of senior tourism especially in the context of the operation of tourist resorts out of the main holiday season.
\end{abstract}

Słowa kluczowe: podróże seniorów; senior; turystyka seniorów; uniwersytet trzeciego wieku Keywords: senior travel; senior; senior tourism; university of the third age

Otrzymano: 28 czerwca 2021

Received: 28 June 2021

Zaakceptowano: 17 lipca 2021

Accepted: 17 July 2021 


\section{Sugerowana cytacja / Suggested citation:}

Kolasińska, A., Sporek, J. (2021). Preferencje turystyczne seniorów - słuchaczy krakowskich uniwersytetów trzeciego wieku. Prace Komisji Geografii Przemysłu Polskiego Towarzystwa Geograficznego, 35(3), $295-306$. doi: https://doi.org/10.24917/20801653.353.18

\section{WSTĘP}

Od kilkunastu lat obserwuje się na świecie postępujący proces starzenia się społeczeństw. Szacuje się, że w 2050 roku populacja osób w wieku powyżej 60 lat osiągnie 2,1 biliona ludzi (United Nations..., 2019) i choć społeczeństwa poszczególnych regionów świata starzeją się w różnym stopniu, to widać, że proces ten szczególnie postępuje w krajach europejskich, w których osoby starsze (powyżej 65 r. życia) stanowią 19,7\% całej populacji (EuroStat, 2019). Słowo „senior” pochodzi od łacińskiego słowa senex, i oznacza „stary”, przy czym granica wieku senioralnego nie jest na świecie traktowana w taki sam sposób i zazwyczaj waha się pomiędzy 55 a 65 rokiem życia. W Polsce zgodnie z Ustawą z 11 września 2015 roku o osobach starszych (Dz.U. 2015, poz. 1705) osoba starsza to taka, która ukończyła 60 lat. Dotychczasowy stereotyp seniora jako osoby biednej, schorowanej i zainteresowanej zaspokajaniem podstawowych potrzeb ulega w Polsce wyraźnej zmianie (Bylok, 2013), a polscy seniorzy coraz częściej, wzorem amerykańskich i zachodnioeuropejskich rówieśników, zainteresowani są życiem kulturalnym, aktywnością rekreacyjną czy turystyką (Bombol, Słaby, 2011; Bondos, 2013; Bylok, 2011; Kociszewski, 2017a; Motylewski i in., 2011). Ponadto aktywność seniorów wpływa na poziom dłuższej ich samodzielności a w konsekwencji obniża koszty opieki zdrowotnej i socjalnej. Jednym ze sposobów aktywnego starzenia się jest podejmowanie aktywności turystycznej (Gu i in., 2016; Otoo, Kim, Choi, 2020). Przewiduje się, że w wyniku obserwowanej eksplozji demograficznej turystyka seniorów stanie się ewoluującym segmentem rynku (Patterson, Balderas, 2020). Już w 2015 roku 48,8\% obywateli powyżej 65 roku życia pochodzących z krajów Unii Europejskiej przyznało, że podejmuje podróże (Tourism trips of Europeans, 2018). Aby umożliwić szeroki dostęp do różnorodnych form spędzania czasu wolnego dla osób starszych w wielu krajach powstają organizacje mające na celu wspieranie idei aktywnego starzenia się. Należą do nich m.in. uniwersytety trzeciego wieku (UTW). Poprzez swoją działalność i bogatą ofertę umożliwiają osobom starszym rozwój intelektualny, aktywność fizyczną, a przynależność do nich wiąże się także z nawiązywaniem i rozwojem kontaktów towarzyskich. W ramach prowadzonej działalności UTW organizują także podróże turystyczne krajowe i zagraniczne. Słuchacze polskich UTW uważani są za najbardziej aktywnych seniorów wśród osób powyżej 60 roku życia (Głąbiński, 2018; Śniadek, Górka, 2016), a kształcący się seniorzy to zdaniem Borczyk (2009) polski fenomen XXI wieku. Wśród licznych badań nad turystyką seniorów (Borges Tiago i in., 2016; Hsu, Kang, 2009; Kociszewski, 2021; Lehto i in., 2008) kilka dotyczy preferencji turystycznych (Agrusa, Kim, 2008; Moschis, Unal, 2008; Spasojević, Božić, 2016) i związanych z nimi motywacji. Przedmiotem zainteresowania badaczy stają się także słuchacze UTW w kontekście podejmowanej przez nich aktywności turystycznej (Śniadek, Górka, 2016; Zawadka, 2016). Seniorzy uniwersytetów trzeciego wieku stanowią wyjątkowy segment dla rynku turystycznego, ponieważ już sam udział w zajęciach uniwersyteckich świadczy o tym, że są to osoby żywo zainteresowane rożnego rodzaju aktywnościami. Jak podkreśla Otoo i in. (2020) bez analizy charakterystyki seniorów według 
segmentów, dostawcy usług turystycznych nie są w stanie przygotować programów turystycznych zgodnych z preferencjami osób starszych. Zasadniczym celem prowadzonych badań była ocena preferencji turystycznych seniorów zrzeszonych w uniwersytetach trzeciego wieku na przykładzie Krakowa. W pracy postawiono następujące pytania badawcze: 1. Jakie preferencje w zakresie organizacji podróży przejawiają seniorzy? 2. Jakie aktywności podejmują seniorzy podczas wyjazdów turystycznych? 3. Na jakie bariery w podejmowaniu aktywności turystycznej wskazują seniorzy?

\section{UNIWERSYTETY TRZECIEGO WIEKU}

Na problem związany z aktywizacją i kształceniem osób starszych jako pierwszy w Europie zwrócił uwagę prof. Pierre Vellas z uniwersytetu w Tuluzie. W 1972 roku otworzył w tym mieście letnią szkołę dla emerytów, która osiągnęła wielki sukces wśród seniorów. Rosnąca popularność szkoły skłoniła Vellasa do powołania w 1973 roku pierwszego uniwersytetu trzeciego wieku przeznaczonego dla wszystkich osób, które osiągnęły wiek emerytalny (Śniadek, Górka, 2016). Kolejne UTW powstawały m.in. w Szwajcarii, Polsce, Belgii i we Włoszech.

W Polsce pierwszy UTW założono w Warszawie w 1975 roku (Hrapkiewicz, 2009). Prekursorką tego typu nauczania seniorów była prof. Halina Szwarc. Ogromne zainteresowanie seniorów tą formą aktywności sprawiło, że liczba uniwersytetów systematycznie rośnie, zwłaszcza od początku XXI wieku, a w roku 2018 wyniosła 640 placówek (GUS, 2019). Są one prowadzone głównie w formie stowarzyszeń (56\%), jako jednostki działające przy uczelniach wyższych (22\%), a także jako formy działalności domów kultury (blisko 18\%). W Polsce UTW funkcjonują w oparciu o model francuski, który zakłada współpracę z ośrodkami akademickimi poprzez aktywność w zakresie dydaktyki. Zajęcia, na jakie uczęszczać mogą seniorzy, obejmują nie tylko wykłady czy seminaria, ale także warsztaty, zajęcia ruchowe, wycieczki, a nawet kursy zawodowe. W 2018 roku na UTW w Polsce studiowało łącznie 113,2 tys. słuchaczy, w tym 95,4 tys. kobiet. Większość (ok. 88\%) z nich było emerytami (GUS, 2019).

\section{TURYSTYKA SENIORÓW}

Rosnące zainteresowanie turystyką seniorów jest obserwowane od początku XXI wieku (Jang i in., 2009), wcześniej uwaga osób odpowiedzialnych za kreowanie produktów turystycznych była w dużej mierze skupiona na młodszych konsumentach, przy jednoczesnej ignorancji starszych uczestników ruchu turystycznego (Szmigin, Carrigan, 2001). Tymczasem jak pokazują badania (Horneman i in., 2002; Moschis, Unal, 2008), seniorzy nie tworzą jednolitego segmentu rynku, co ma istotne znaczenie w rozwoju produktów turystycznych skierowanych do tej grupy konsumentów. Borges Tiago i in. (2016); Dattilo i in. (2015); Kazeminia, Del Chiappa, Jafari, (2015) dowodzą, że seniorzy różnią się m.in. preferencjami i motywacjami w zakresie podróży. Patterson i Balderas (2020) zauważyli, że jednym z rezultatów różnorodności i zróżnicowania rynku seniorów jest to, że wymagają oni rozmaitych form podróżowania dostoswanych do swoich potrzeb. Można przypuszczać, że zapotrzebowanie na turystykę w tej grupie konsumentów będzie stale rosło, ponieważ jest ona traktowana jako ważny aspekt życia seniorów, który został uznany za poprawiający samopoczucie psychiczne i fizyczne (Kendig, Browning, 2016) a doświadczenia związane z podróżowaniem prowadzą do większej satysfakcji 
z życia (Kim, Woo, Uysal, 2015). Ponadto cechy rynku turystycznego seniorów wskazywane w literaturze (Gu i in., 2016; Śniadek, 2006) takie jak: dynamika wzrostu, duży budżet czasu wolnego i zainteresowanie seniorów turystyką poza głównym sezonem sprawiają, że rynek ten ma ogromne znaczenie dla branży turystycznej. Tym bardziej kluczowa wydaje się znajomość preferencji seniorów zwłaszcza dla dostawców usług turystycznych.

\section{METODYKA PROWADZONYCH BADAŃ}

W prezentowanych badaniach wykorzystano metodę badań sondażowych, z zastosowaniem autorskiego kwestionariusza ankiety. Badania zostały przeprowadzone w styczniu 2020 roku wśród słuchaczy trzech krakowskich uniwersytetów trzeciego wieku (UTW Uniwersytetu Jagiellońskiego, UTW Uniwersytetu Jana Pawła II, UTW Politechniki Krakowskiej) w trakcie zajęć odbywających się w budynkach uniwersyteckich. Ankiety w formie papierowej były rozdawane uczestnikom do samodzielnego wypełnienia, a badacz był obecny w trakcie procedury zbierania danych. W badaniach zastosowano kwestionariusz ankiety składający się z dwóch zasadniczych części. W pierwszej części znalazło się 6 pytań dotyczących profilu socjologiczno-demograficznego respondentów. Druga część kwestionariusza obejmowała 16 pytań dotyczących zachowań turystycznych respondentów (m.in. częstotliwości wyjazdów, celu podejmowanych podróży, wydatków przeznaczonych na podróże, barier w podejmowaniu aktywności turystycznej, a także preferencji w zakresie środka transportu i zakwaterowania). W pytaniach dotyczących: aktywności podejmowanych w czasie wyjazdów, barier ograniczających wyjazdy, czynników decydujących o wyborze oferty turystycznej, a także preferowanych miejscach docelowych ankietowani byli proszeni o podanie maksymalnie trzech odpowiedzi. W pozostałych pytaniach wymagane było jedno wskazanie. Druga część kwestionariusza została opracowana w oparciu o przegląd literatury dotyczącej turystyki seniorów (Jang i in., 2009; Spasojević, Božić, 2016; Zawadka, 2016).

\section{WYNIKI}

W badaniach wzięło udział 212 respondentów, co stanowiło około 17\% aktywnych słuchaczy badanych uniwersytetów trzeciego wieku. 86\% badanych stanowiły kobiety, a 14\% mężczyźni. Większość ankietowanych (88\%) była w wieku pomiędzy 61 a 75 rokiem życia, przebywała na emeryturze (93\%) oraz zadeklarowała wyższe wykształcenie (68\%). Szczegółową charakterystykę przedstawiono w tabeli 1. Do podróżowania przyznało się aż 95\% respondentów i ich odpowiedzi zostały poddane dalszej analizie.

Tabela 1. Charakterystyka socjologiczno-demograficzna respondentów

\begin{tabular}{|l|r|l|r|r|}
\hline \multicolumn{2}{|c|}{ Płeć } & \multicolumn{3}{c|}{ Miejsce zamieszkania } \\
\hline kobiety & $86 \%$ & miasto & $95 \%$ \\
\hline mężczyźni & $14 \%$ & wieś & $5 \%$ \\
\hline \multicolumn{2}{|c|}{ Wiek } & $4 \%$ & emerytura & $93 \%$ \\
\hline do 60 lat & $88 \%$ & renta & $2 \%$ \\
\hline 61-75 lat & $8 \%$ & inne & $5 \%$ \\
\hline powyżej 75 lat & \multicolumn{3}{c}{} \\
\hline
\end{tabular}




\begin{tabular}{|l|c|l|c|}
\hline \multicolumn{2}{|c|}{ Stan cywilny } & \multicolumn{2}{c|}{ Wykształcenie } \\
\hline zamężna/żonaty & $53 \%$ & podstawowe & $0 \%$ \\
\hline wdowa/wdowiec & $22 \%$ & zawodowe & $30 \%$ \\
\hline panna/kawaler & $15 \%$ & średnie & $68 \%$ \\
\hline rozwiedziona/rozwiedziony & $10 \%$ & wyższe & \\
\hline
\end{tabular}

Źródło: opracowanie własne

Aż 67\% badanych zadeklarowało, że w ciągu roku odbywa od 1 do 3 wyjazdów, przy czym aż 69\% ankietowanych deklaruje wyjazdy krajowe. Zdecydowanie najwięcej osób decyduje się na wyjazd w celu turystyczno-wypoczynkowym (68\%) (rycina 1). Znacznie mniej osób jako główny cel podało odwiedzanie rodziny i przyjaciół (11\%) oraz pobudki religijne (10\%), cel zdrowotny zadeklarowało zaledwie $5 \%$ respondentów. Do obszarów najczęściej wybieranych przez seniorów jako miejsce podróży należą: obszary nadmorskie (71\%) oraz góry (64\%), a stosunkowo rzadko wieś (18\%) i obszary położne nad jeziorami (17\%).

Określając preferencje w zakresie organizacji wyjazdu (tabela 2) należy stwierdzić, że seniorzy w podobnym stopniu wybierają podróże organizowane samodzielnie (33\%) i przez biura podróży (32\%). Podobnie wygląda sytuacja w wyborze środka transportu, do najczęściej używanych należy samochód (36\%) i autokar (36\%). Słuchacze UTW jako towarzystwo w podróży preferują rodzinę (30\%) a wybierają niski sezon turystyczny (maj-wrzesień) (60\%). Większość (30\%) decyduje się na usługi noclegowe oferowane przez hotele niższej klasy, deklarując wydatki na jeden wyjazd w kwocie do $1000 \mathrm{zt}$.

Rycina 1. Główny cel wyjazdów turystycznych słuchaczy UTW

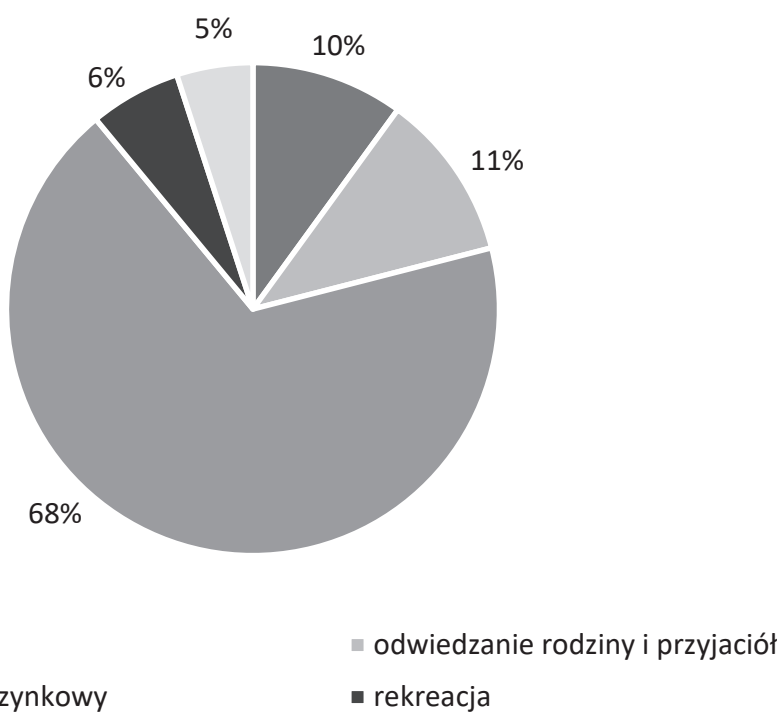

- religijny

- turystyczno-wypoczynkowy

poprawa zdrowia/wyjazd do uzdrowisk 
Tabela 2. Preferencje seniorów w zakresie organizacji wyjazdów turystycznych

\begin{tabular}{|c|c|c|c|}
\hline \multicolumn{2}{|l|}{ Środek transportu } & \multicolumn{2}{|c|}{ Średnie wydatki na 1 wyjazd } \\
\hline samochód & $36 \%$ & do $1000 \mathrm{zł}$ & $40 \%$ \\
\hline autokar & $36 \%$ & $100-1999 \mathrm{zł}$ & $31 \%$ \\
\hline samolot & $19 \%$ & $2000-2999 \mathrm{zł}$ & $18 \%$ \\
\hline pociąg & $9 \%$ & powyżej 2999 zł & $11 \%$ \\
\hline \multicolumn{2}{|l|}{ Sposób organizacji wyjazdów } & \multicolumn{2}{|c|}{ Towarzystwo w podróży } \\
\hline samodzielnie & $33 \%$ & rodzina & $30 \%$ \\
\hline biuro podróży & $32 \%$ & grupa zorganizowana & $26 \%$ \\
\hline UTW & $14 \%$ & partner & $18 \%$ \\
\hline rodzina, znajomi & $12 \%$ & przyjaciele & $15 \%$ \\
\hline organizacje kościelne & $5 \%$ & samotnie & $11 \%$ \\
\hline inne & $4 \%$ & & \\
\hline \multicolumn{2}{|l|}{ Termin wyjazdu } & \multicolumn{2}{|c|}{ Zakwaterowanie } \\
\hline niski sezon (maj, wrzesień) & $60 \%$ & hotele $1-3^{*}$ & $30 \%$ \\
\hline sezon letni (czerwiec, lipiec, sierpień) & $27 \%$ & hotele $4-5^{*}$ & $20 \%$ \\
\hline $\begin{array}{l}\text { poza sezonem (marzec, kwiecień, } \\
\text { październik, listopad) }\end{array}$ & $11 \%$ & pensjonaty & $19 \%$ \\
\hline \multirow[t]{3}{*}{ sezon zimowy (grudzień, styczeń, luty) } & $2 \%$ & pokoje gościnne & $17 \%$ \\
\hline & & apartamenty & $9 \%$ \\
\hline & & gospodarstwa agroturystyczne & $5 \%$ \\
\hline
\end{tabular}

Źródło: opracowanie własne

Rycina 2. Aktywności podejmowane przez seniorów podczas wyjazdów turystycznych (możliwość wskazania 3 odpowiedzi)

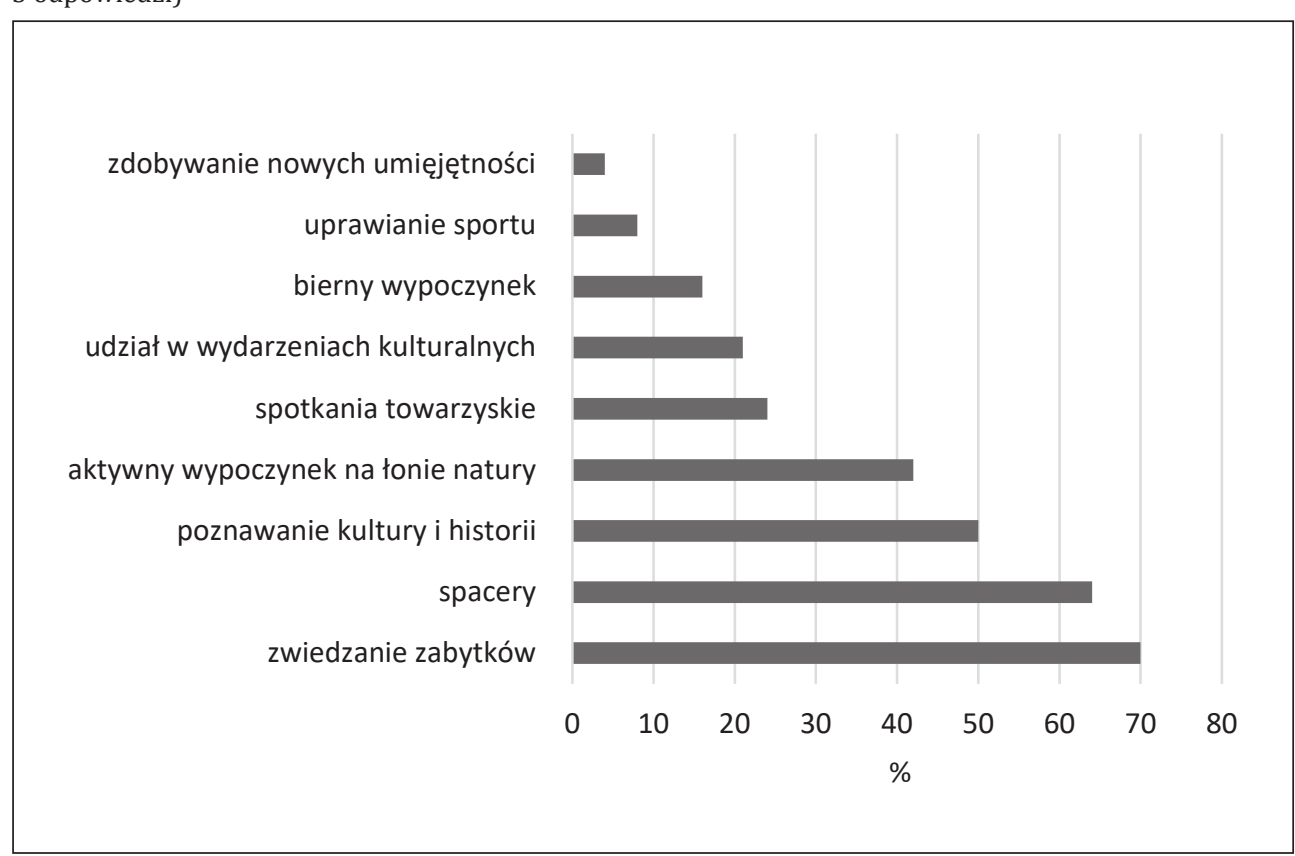

Źródło: opracowanie własne 
Rycina 3. Bariery w podejmowaniu aktywności turystycznej seniorów (możliwość wskazania 3 odpowiedzi)

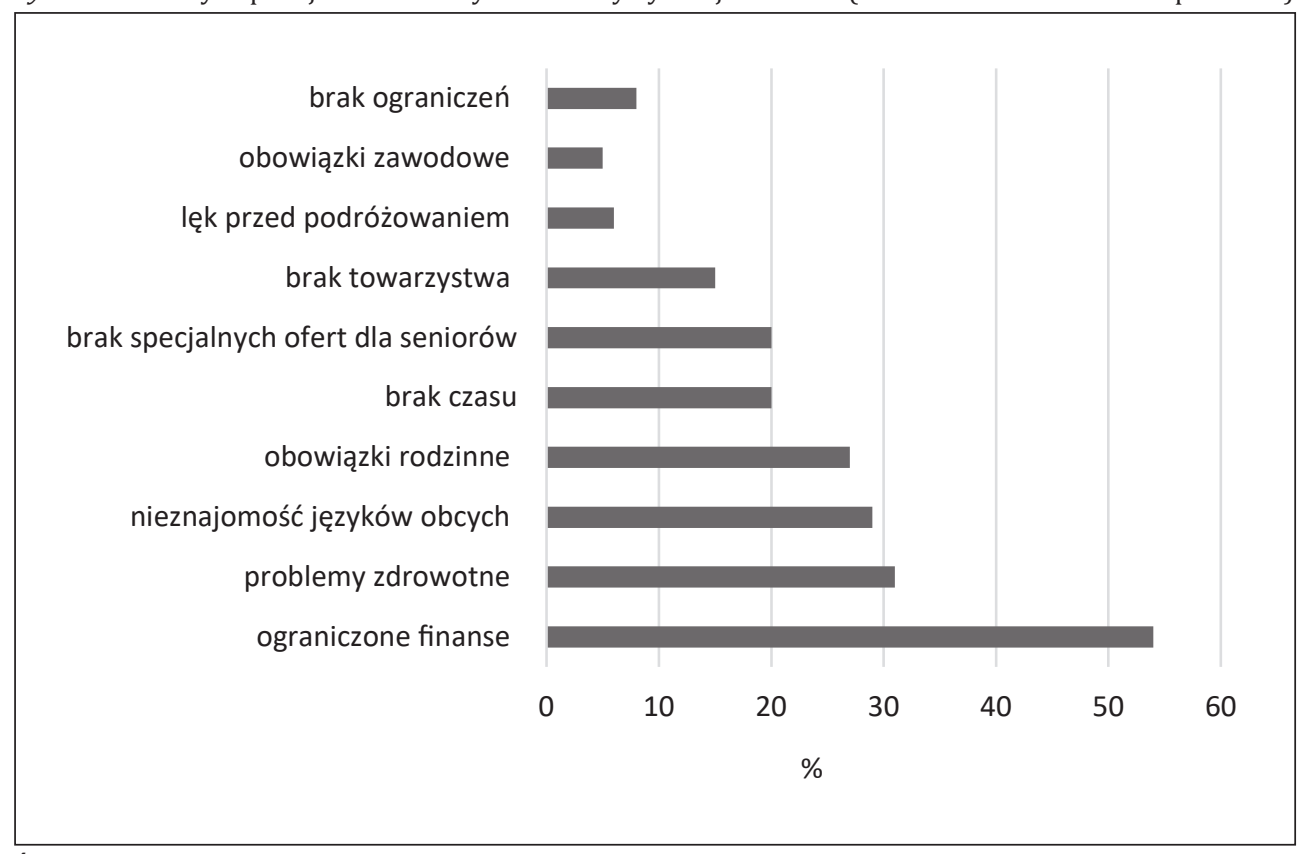

Źródło: opracowanie własne

Analizując aktywności podejmowane przez seniorów podczas wyjazdów należy stwierdzić, że najchętniej zwiedzają oni zabytki (70\%) oraz spacerują (64\%). Starsze osoby wybierają także aktywności związane z poznawaniem kultury i historii (50\%). Aktywny wypoczynek na łonie natury jest aktywnością lubianą przez $42 \%$ seniorów. Nieco mniej ankietowanych decyduje się na bierny wypoczynek na plaży (16\%). Najmniej liczne grupy seniorów decydują się na uprawianie sportu (8\%) oraz zdobywanie nowych umiejętności (4\%) (rycina 2).

Ważną częścią badań było także określenie barier, które mogą ograniczać aktywność turystyczną seniorów (rycina 3). Ponad połowa respondentów za najważniejszą przeszkodę wskazała ograniczenia finansowe (54\%). Problemy zdrowotne stanowią barierę dla 31\% respondentów, a nieznajomość języków obcych dla 29\%. Najmniej istotnymi przeszkodami okazał się lęk przed podróżowaniem (6\%) oraz obowiązki zawodowe (5\%) - dla osób, które wciąż są aktywne zawodowo. Zaledwie 8\% respondentów wskazało, że nie ma żadnych ograniczeń w podejmowaniu aktywności turystycznej.

\section{DYSKUSJA}

Głównym celem przedstawionych badań było określenie preferencji w zakresie podróżowania wśród polskich seniorów - słuchaczy UTW. Osoby te wyróżniają się ogólną aktywnością na tle polskich seniorów, dlatego też wyników tych nie należy odnosić do ogółu populacji osób starszych. Seniorzy aktywnie uczestniczący w zajęciach uniwersytetów trzeciego wieku stanowią zaledwie $1 \%$ populacji osób powyżej 61 roku życia (GUS, 2021). 
Ankietowani najczęściej wyjeżdżają w celach turystyczno-wypoczynkowych a zdecydowana większość wybiera wyjazdy krajowe, podobnie jak inni europejscy seniorzy, którzy również najczęściej decydują się na podróże po własnym kraju (Alén, Losada, Domínguez, 2016; Borges Tiago i in., 2016), chociaż trend taki spotykany jest także poza Europą (Lee, Tideswell, 2005). W przypadku turystyki krajowej seniorzy nie muszą obawiać się trudności w komunikacji, które mogą się pojawić za granicą. Jak się okazuje, brak znajomości języków obcych wśród słuchaczy UTW stanowi jedną z barier podejmowania aktywności turystycznej, na co zwróciły uwagę również Dubińska (2015) i Górna (2015). Ponadto preferencje w zakresie wyjazdów krajowych podyktowane są zapewne mniejszymi kosztami wyjazdów niż w przypadku podróży zagranicznych. Ograniczone możliwości finansowe są dla polskich seniorów ważną barierą w podejmowaniu podróży. Na taką sytuację wskazywali także inni polscy badacze (Bielecka, Parzonko, 2016; Dubińska, 2015). Podobne ograniczenia mają także seniorzy w Serbii (Spasojević, Božić, 2016). Do istotnych przeszkód wskazywanych przez respondentów, należały także problemy zdrowotne, na co zwrócili uwagę także Alén, Losada, Domínguez (2016). Zastanawiające może wydawać się, że zdrowotny cel wyjazdów był bardzo rzadko wskazywany przez respondentów (5\%), natomiast zarówno w badaniach nad turystyką seniorów prowadzonych przez Borges Tiago i in. (2016), jak i Spasojević i Božić (2016) poprawa zdrowia jako cel wyjazdu była znacznie częściej wskazywana przez seniorów.

Wśród aktywności podejmowanych podczas wyjazdu turystycznego polscy seniorzy najczęściej wymieniają zwiedzanie zabytków i spacery. Na popularność tych ostatnich zwrócił także uwagę Batra (2009) badając aktywność turystów seniorów odwiedzających Tajlandię. Podobne preferencje osób starszych zauważyła Górna (2015), która wspomniała także o aspektach zdrowotnych spacerów oraz o ich pozytywnym wpływie na ludzki organizm. Zwiedzanie miejsc o znaczeniu historycznym jest także popularne wśród hiszpańskich seniorów (Alén, Losada, Domínguez, 2016). Śledząc natomiast wyniki badań w zakresie turystyki seniorów z różnych części świata można zaobserwować nieco odmienne sposoby spędzania czasu podczas wyjazdów turystycznych. Chen i Shoemaker (2014) zwrócili uwagę, że amerykańscy seniorzy preferują zakupy, czy wizyty w kasynie, Serbowie preferują aktywności na łonie natury oraz zabiegi spa (Spasojević, Božić, 2016). Australijscy seniorzy najchętniej zwiedzają obszary o naturalnym lub wiejskim, a także historycznym charakterze (Horneman i in., 2002). Rozpatrując obecność towarzyszy w podejmowaniu podróży należy stwierdzić, że Polacy preferują wyjazdy z rodziną lub z grupą zorganizowaną, podobnie hiszpańscy seniorzy najchętniej wyjeżdżają w towarzystwie rodziny i przyjaciół (Alén, Losada, Domínguez, 2016) a w towarzystwie partnera obywatele Stanów Zjednoczonych i Kanady (Otoo, Kim, Choi i in., 2020). 0 istocie bliskich relacji seniorów z rodziną pisała Borowik (2015), która w swoich badaniach wykazała, że rodzina jest dla osób starszych jedną z najważniejszych wartości. Wspominała także o konieczności międzypokoleniowej wymiany doświadczeń. Dobrym rozwiązaniem dla osób starszych, które lubią spędzać czas ze swoimi najbliższymi, są wakacje z wnukami, dla których dziadkowie są źródłem mądrości życiowej (Pieńkos, 2016). Niezwykle ważną kwestią w turystyce seniorów są ich preferencje w zakresie zakwaterowania. Krakowscy seniorzy wybierali najczęściej hotele, podobnie jak hiszpańscy (Alén, Losada, Domínguez, 2016) i szwajcarscy (Boksberger, Laesser, 2009). W przypadku polskich badań rozpatrywane były jeszcze kategorie hoteli, a rozróżnienia tego nie było w porównywanych sondażach. 
Polscy seniorzy na podobnym poziomie (ok. 30\%) jak hiszpańscy korzystają przy organizacji wyjazdów z usług biur podróży (Alén i in., 2016). W zakresie środka transportu używanego podczas podróży seniorzy tak samo często wybierają samochód osobowy, jak i autokar, co zapewne ma związek z dużym zainteresowaniem polskich seniorów podróżami w grupach zorganizowanych. W badaniach Boksberger i Laesser (2009) respondenci również wskazywali na samochód osobowy jako najchętniej wybierany w czasie podróży, ale przy zdecydowanie mniejszym zainteresowaniu autokarem. Warto wreszcie zauważyć, że zdecydowana większość badanych seniorów wybiera na czas podróży miesiące poza głównym sezonem wakacyjnym, co może być ważnym komunikatem dla organizatorów turystyki. Taką samą prawidłowość dostrzegli Alén, Losada, Domínguez (2016) oraz Oliveira, Brochado, Correia (2018). W tych miesiącach seniorzy chętnie podejmują wyjazdy, ponieważ miejsca turystyczne są mniej zatłoczone a oferują swoje usługi i atrakcje. Podróżowanie w niskim sezonie może przynieść też pewne korzyści finansowe, ponieważ z części ofert można skorzystać w promocyjnych cenach. Dzięki podróżom poza głównym sezonem wakacyjnym, seniorzy mogą przyczynić się do minimalizowania sezonowości w branży turystycznej (Głąbiński, 2019). Profilowanie przez organizatorów turystyki oferty dla seniorów z uwzględnieniem ich preferencji może stać się ponadto elementem przewagi konkurencyjnej, na co w swoich badaniach zwrócił uwagę Kociszewski (2017b).

\section{PodSumowANiE}

Grupa tworzona przez seniorów słuchaczy UTW cechuje się różnorodnością i trudno w jej obrębie wyznaczyć cechy charakterystyczne dla wszystkich jej członków. Nie ma żadnej ściśle wyznaczonej granicy wieku, po której przekroczeniu człowiek nagle zmienia swoje przyzwyczajenia, osobowość i mentalność, aby można było go zaklasyfikować do ogólnie przyjętego wizerunku seniora. Grupa ta, choć wyróżnia się wyższym wykształceniem, miejscem zamieszkania (miasto) i płcią (większość kobiet) jest zróżnicowana pod względem różnych aspektów związanych z podejmowaniem aktywności turystycznej. Grupa seniorów słuchaczy UTW, staje się segmentem o dużym potencjale turystycznym, cechuje ją bowiem dużo większa aktywność turystyczna niż grupę wszystkich seniorów w Polsce. Dlatego też, istotne wydaje się, aby preferencje seniorów dotyczące zakwaterowania, współtowarzyszy podróży, środka transportu czy też głównego celu wyjazdu były brane pod uwagę przez organizatorów turystyki. Niemniej ważne pozostaje niwelowanie barier, zwłaszcza tych finansowych. Tylko takie podejście sprawi, że podróż dla seniorów będzie się wiązać z satysfakcją i przyjemnością, a dla branży stanie się ważnym segmentem konsumentów, zwłaszcza w kontekście problemu sezonowości turystyki.

\section{Literatura}

\section{References}

Agrusa, J., Kim, S.S. (2008). Understanding preferences and characteristics of Japanese tourists to Hawaii. Tourism Analysis, 13(5-6), 485-497. doi: https://doi.org/10.3727/ 108354208788160487.

Alén, E., Losada, N., Domínguez, T. (2016). The Impact of Ageing on the Tourism Industry. An Approach to the Senior Tourist Profile. Social Indicators Research, 127(1), 303-322. doi: https://doi.org/10.1007/s11205-015-0966-x. 
Batra, A. (2009). Senior pleasure tourists. Examination of their demography, travel experience, and travel behavior upon visiting the Bangkok metropolis. International Journal of Hospitality and Tourism Administration, 10(3), 197-212. doi: https://doi.org/10.1080/15256480903088105.

Bielecka, K., Parzonko, A.J. (2016). Preferencje osób starszych uczestniczących w wyjazdach turystycznych. Journal of Tourism and Regional Development, 6, 5-12.

Boksberger, P.E., Laesser, C. (2009). Segmentation of the senior travel market by the means of travel motivations. Journal of Vacation Marketing, 15(4), 311-322. doi: https://doi. org/10.1177/1356766709335829.

Bombol, M., Słaby, T. (2011). Konsument 55+ wyzwaniem dla rynku. Warszawa: Oficyna Wydawnicza SGH.

Bondos, I. (2013). Dlaczego seniorzy stanowią wyzwanie dla marketingu? Marketing i Rynek, $3(8), 31-36$.

Borczyk, W. (2009). Edukacja osób starszych. Rola i znaczenie Uniwersytetów Trzeciego Wieku. Małopolskie Studia Regionalne, 2(17), 31-37.

Borges Tiago, M.T.P.M., Couto, J.P. de A., Tiago, F.G.B., Dias Faria, S.M.C. (2016). Baby boomers turning grey. European profiles. Tourism Management, 54, 13-22. doi: https://doi.org/10.1016/j. tourman.2015.10.017.

Borowik, J. (2015). Znaczenie relacji rodzinnych w życiu osób starszych. W: I. Taranowicz, S. Grotowska (red.), Rodzina wobec wyzwań współczesności. Wrocław: Oficyna Wydawnicza Arboretum, 139-150.

Bylok, F. (2011). Strategie zachowań konsumpcyjnych seniorów na rynku dóbr i usług konsumpcyjnych. Problemy Zarządzania, 11(1), 124-142.

Bylok, F. (2013). Zachowania konsumpcyjne seniorów na rynku dóbr i usług. Acta Universitatis Lodziensis. Folia Oeconomica, 139-151.

Chen, S. C., Shoemaker, S. (2014). Age and cohort effects. The American senior tourism market. Annals of Tourism Research, 48, 58-75. doi: https://doi.org/10.1016/j.annals.2014.05.007.

Dattilo, J., Lorek, A. e, Mogle, J., Sliwinski, M., Freed, S., Frysinger, M., Schuckers, S. (2015). Perceptions of Leisure by Older Adults Who Attend Senior Centers. Leisure Sciences, 37(4), 373-390. doi: https://doi.org/10.1080/01490400.2015.1016563.

Dubińska, A. (2015). Aktywność fizyczna i turystyczna wśród uczestników Uniwersytetów Trzeciego Wieku na przykładzie Krakowa. Przedsiębiorczość-Edukacja, 11, 351-361. doi: https://doi.org/10.24917/20833296.11.27.

EuroStat. (2019). Ageing Europe. Looking at the lives of older people in the EU. 2019 edition. Publications Office of the European Union. Pozyskano z https://ec.europa.eu/eurostat/web/ products-statistical-books/-/KS-02-19-681

Głąbiński, Z. (2018). Determinants of Senior Tourist Activity in Light of Contemporary Research. Folia Turistica, 46, 49-75. doi: https://doi.org/10.5604/01.3001.0012.0846.

Głąbiński, Z. (2019). Stymulowanie aktywności turystycznej seniorów jako sposób łagodzenia zjawiska sezonowości na polskim wybrzeżu Bałtyku. W: A. Cedro (red.), Polska Geografia Morza. Przyrodnicze i społeczno-ekonomiczne badania morza 76 i obszarów nadmorskich. Szczecin: Wydział Nauk o Ziemi Uniwersytetu Szczecińskiego, 85-105.

Górna, J. (2015). Preferences and tourist activity of Poles over the age 50 years. Prace Naukowe Akademii im. Jana Długosza w Częstochowie. Kultura Fizyczna, 14(1), 153-166. doi: https:// doi.org/10.16926/kf.2015.14.11.

Gu, D., Zhu, H., Brown, T., Hoenig, H., Zeng, Y. (2016). Tourism Experiences and Self-Rated Health among Older Adults in China. Journal of Aging and Health, 28(4), 675-703. doi: https://doi. org/10.1177/0898264315609906.

GUS. (2019). Uniwersytety trzeciego wieku w Polsce w 2018 r. Wiadomości sygnalne. Pozyskano z stat.gov.pl/obszary-tematyczne/edukacja/edukacja/uniwersytety-trzeciego-wieku-w-polsce-w-2018-r-,10,2.html

GUS. (2021). Sytuacja osób starszych w Polsce w 2019 r. Analizy statystyczne. Warszawa; Białystok. Pozyskano z stat.gov.pl/obszary-tematyczne/osoby-starsze/osoby-starsze/sytuacja-osobstarszych-w-polsce-w-2019-roku,2,2.html

Horneman, L., Carter, R.W., Wei, S., Ruys, H. (2002). Profiling the senior traveler. An Australian perspective. Journal of Travel Research, 41(1), 23-37. doi: https://doi. org/10.1177/004728750204100104 
Hrapkiewicz, H. (2009). Uniwersytety trzeciego wieku jako jedna z form kształcenia osób starszych. Chowanna, 2, 115-126.

Hsu, C.H.C., Kang, S.K. (2009). Chinese Urban Mature Travelers' Motivation and Constraints by Decision Autonomy. Journal of Travel \& Tourism Marketing, 26(7). doi: https://doi. org/10.1080/10548400903284537.

Jang, S., Bai, B., Hu, C., Wu, C.M.E. (2009). Affect, travel motivation, and travel intention. A senior market. Journal of Hospitality and Tourism Research, 33(1), 51-73. doi: https://doi. org/10.1177/1096348008329666.

Kazeminia, A., Del Chiappa, G., Jafari, J. (2015). Seniors' Travel Constraints and Their Coping Strategies. Journal of Travel Research, 54(1), 80-93. doi: https://doi. org/10.1177/0047287513506290.

Kendig, H., Browning, C. (2016). Social research and actions on ageing well. W: H. Kendig, P. McDonald, J. Piggott (red.), Population Ageing and Australia's Future. Australia: ANU Press, 137-164. doi: https://doi.org/10.22459/paaf.11.2016.07.

Kim, H., Woo, E., Uysal, M. (2015). Tourism experience and quality of life among elderly tourists. Tourism Management, 46, 465-476. doi: https://doi.org/10.1016/j.tourman.2014.08.002.

Kociszewski, P. (2017a). Kształtowanie oferty na rynku turystyki kulturowej przez organizatorów turystyki (na przykładzie turystów seniorów). Turystyka Kulturowa, 1, 80-105.

Kociszewski, P. (2017b). Wybrane elementy potencjału konkurencyjności biur podróży na rynku turystyki seniorów w Polsce. Studia Oeconomica Posnaniensia, 5(4), 208-227. doi: https:// doi.org/10.18559/soep.2017.4.10.

Kociszewski, P. (2021). Aktywność turystyczna seniorów w kontekście odkrywania wartości dziedzictwa kulturowego. Turystyka Kulturowa, 1, 116-148.

Lee, S. H., Tideswell, C. (2005). Understanding attitudes towards leisure travel and the constraints faced by senior Koreans. Journal of Vacation Marketing, 11(3), 249-263. doi: https://doi. org/10.1177/1356766705055716

Lehto, X.Y., Jang, S. (Shawn), Achana, F.T., O'Leary, J.T. (2008). Exploring tourism experience sought: A cohort comparison of Baby Boomers and the Silent Generation. Journal of Vacation Marketing, 14(3). doi: https://doi.org/10.1177/1356766708090585.

Moschis, G., Unal, B. (2008). Travel and leisure services preferences and patronage motives of older consumers. Journal of Travel and Tourism Marketing, 24(4), 259-269. doi: https://doi. org/10.1080/10548400802156711.

Motylewski, S., Pawlicka-Lisowska, A., Gątkiewicz, M., Poziomska-Piątkowska, E. (2011). Aktywność fizyczna studentek Uniwersytetu Trzeciego Wieku przy Uniwersytecie Medycznym w Łodzi. Kwartalnik Ortopedyczny, 37-43.

Oliveira, C., Brochado, A., Correia, A. (2018). Seniors in international residential tourism. Looking for quality of life. Anatolia, 29(1), 11-23. doi: https://doi.org/10.1080/13032917.2017.13 58189.

Otoo, F. E., Kim, S., Choi, Y. (2020). Understanding senior tourists' preferences and characteristics based on their overseas travel motivation clusters. Journal of Travel and Tourism Marketing, 37(2), 246-257. doi: https://doi.org/10.1080/10548408.2020.1740136.

Patterson, I., Balderas, A. (2020). Continuing and Emerging Trends of Senior Tourism. A Review of the Literature. Journal of Population Ageing, 13(3), 385-399. doi: https://doi.org/10.1007/ s12062-018-9228-4.

Pieńkos, M. (2016). Dziadkowie w wychowaniu wnuków na podstawie opinii osób młodych i starszych. Forum Pedagogiczne, 5(2), 279-289. doi: https://doi.org/10.21697/fp.2015.2.10.

Śniadek, J. (2006). Age of Seniors - a Challenge for Tourism and Leisure Industry. Studies in Physical Culture and Tourism, 13, 103-105.

Śniadek, J., Górka, J. (2016). Tourist Activity of University of the Third Age's Students on the Example of Selected Institutions in Wielkopolska (Greater Poland). Ekonomiczne Problemy Turystyki, 34, 107-118. doi: https://doi.org/10.18276/ept.2016.2.34-09.

Spasojević, B., Božić, S. (2016). Senior tourists' preferences in the developing countries - measuring perceptions of Serbian potential senior market. European Journal of Tourism, Hospitality and Recreation, 7(2), 74-83. doi: https://doi.org/10.1515/ejthr-2016-0009.

Szmigin, I., Carrigan, M. (2001). Learning to love the older consumer. Journal of Consumer Behaviour, 1(1). doi: https://doi.org/10.1002/cb.51. 
Tourism trips of Europeans (2018). Eurostat online publication providing recent statistics on tourism demand in the European Union (EU). The tourism trips made by EU residents. Pozyskano z https://ec.europa.eu/eurostat/statistics-explained/index.php?title=Tourism_ trips_of_Europeans

United Nations, Department of Economic and Social Affairs, Population Division. (2019). World Population Prospects 2019. Highlights (ST/ESA/SER.A/423). Pozyskano z https://population.un.org/wpp/Publications/

Zawadka, J. (2016). Characteristics of Tourist Activity of Seniors in Poland. Ekonomiczne Problemy Turystyki, 34, 119-129. doi: https://doi.org/10.18276/ept.2016.2.34-10.

Anna Kolasińska, doktor, adiunkt, Uniwersytet Pedagogiczny w Krakowie, Instytut Geografii, Katedra Turystyki i Badań Regionalnych, przewodnik turystyczny. Zainteresowania naukowe obejmują zagadnienia związane z turystycznym użytkowaniem cennych obszarów przyrodniczych, w szczególności wpływu turystów na parki narodowe, a także zagadnienia związane z turystyką kulturową w Krakowie.

Anna Kolasińska, PhD, assistant professor, Pedagogical University of Krakow, Institute of Geography, Department of Tourism and Regional Studies, tourist guide. Her research area includes the issues of the tourist use of valuable natural areas, in particular the impact of tourism on national parks, as well as issues related to cultural tourism in Krakow.

ORCID: https://orcid.org/0000-0001-6990-0128

\section{Adres/address:}

Uniwersytet Pedagogiczny w Krakowie

Instytut Geografii

Katedra Turystyki i Badań Regionalnych

ul. Podchorążych 2

30-084 Kraków, Polska

e-mail: anna.kolasinska@up.krakow.pl

Joanna Sporek, magister, absolwentka kierunku turystyka i rekreacja, Uniwersytet Pedagogiczny w Krakowie, Instytut Geografii, Katedra Turystyki i Badań Regionalnych. Jej zainteresowania badawcze koncentrują się wokół turystyki różnych grup wiekowych, a w szczególności turystyki seniorów.

Joanna Sporek, MA in tourism and recreation, Pedagogical University of Krakow, Institute of Geography, Department of Tourism and Regional Studies Her research area includes the issues related to tourism of different age groups, in particular tourism of seniors.

\section{ORCID: https://orcid.org/0000-0003-4514-6479}

\section{Adres/address:}

Uniwersytet Pedagogiczny w Krakowie

Instytut Geografii

Katedra Turystyki i Badań Regionalnych

ul. Podchorążych 2

30-084 Kraków, Polska

e-mail: jsporek@vp.pl 